\title{
SiM
}

\section{Developing Sources of Native Grass Seed for Revegetation in Florida}

\author{
By Mary J. Williams, Janet Grabowski, and Brandee Williams
}

\section{On the Ground}

- As with much of the eastern United States, the native plant communities present in Florida when European settlers arrived have been converted to cropland, pastureland, and industrial forest production.

- Increasingly, both public and private entities have been making efforts to restore some of the converted acreage to a semblance of the original plant community for reasons of water quality, wildlife habitat, and aesthetics.

- The lack of a commercial source of seed for Florida ecotypes of native grasses is one of the main costs associated with current revegetation efforts.

- A long-term program, by the USDA, NRCS, Brooksville Plant Materials Center and various cooperating public and private institutions, has fostered the development of a commercial, native grass-seed industry in the state.

Keywords: native seed production, evaluation, native vegetation, restoration, rangeland.

Rangelands 35(5):93-97

doi: 10.2111/RANGELANDS-D-13-00024.1

(C) 2013 The Society for Range Management

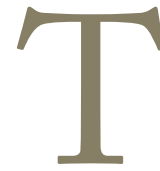

he native seed industry in much of the deep south, and in Florida, in particular, has lagged behind other areas of the country, partly because of a historical lack of demand but also because of a lack of appropriate technology to raise and harvest native species. Government regulations for highway beautification in the 1980s fostered demand and promoted the development of a native wildflower seed industry with the help of researchers at the University of Florida, but the seed production of native grasses lagged, even as demand increased. During the past 30 years, an extensive amount of work has been conducted by the US Department of Agriculture (USDA) Brooksville Plant Materials Center and cooperating agencies, toward the goal of developing a commercially viable, native grass-seed industry for Florida, the site of the 67th Society for Range Management Annual Meet- ing, From Dusty Trails to Waning Wetlands. ${ }^{\mathrm{i}}$ In this article, we provide some background for this effort and its current status.

\section{History of "Improvements" in Florida}

Unlike most of the eastern United States, which was heavily wooded when European settlers arrived, early settlers in Florida were confronted with almost 34 million acres of native range vegetation. ${ }^{1}$ The native vegetation on Florida rangelands included grasses and grasslike species (e.g., sedges and rushes), forbs, and shrubs suitable for grazing and browsing use by livestock and wildlife. An overstory of trees was found on some range sites, whereas others were composed of mostly herbaceous plants. Currently, only about seven million acres of native rangeland remain in the state.

In Florida, inadvertent loss of the native rangeland vegetation through improper grazing management often necessitated "improvements" to maintain adequate forage production. The grazing livestock the early settlers brought with them were initially responsible for shifts in the composition of native vegetation. Species such as lopsided indiangrass (Sorghastrum secundum), eastern gamagrass (Tripsacum dactyloides), purple bluestem (Andropogon glaucopsis), and switchgrass (Panicum virgatum) are preferred by cattle and can be easily grazed out when grazing is not managed. ${ }^{2}$ As the highquality, warm-season bunch grasses were almost grazed out of existence, they were replaced first by less-palatable and lessproductive native species, such as wiregrass or Beyrich threeawn (Aristida beyrichiana $=$ Aristida stricta var. beyrichiana) or bluestem broomsedge (Andropogon virginicus). ${ }^{2}$ Eventually, however, livestock producers cleared large areas of native vegetation and planted nonnative, sod-forming grasses, such as bahiagrass (Paspalum notatum) or bermudagrass (Cynodon dactylon), which required fertilizer inputs but were tolerant of much-laxer grazing management. ${ }^{3}$

In other cases, "improvements" were the result of deliberate actions when alternative industrial or agriculture uses were found. An example is the phosphate industry in penin-

\footnotetext{
'The 67th SRM Annual Meeting \& Trade Show-From Dusty Trails to Waning Wetlands-will be held in Orlando, Florida, 8-13 February 2014. Join us there to learn more about Florida rangelands. For more information on the 2014 SRM Annual Meeting, see http://www.rangelands.org/events/.
} 


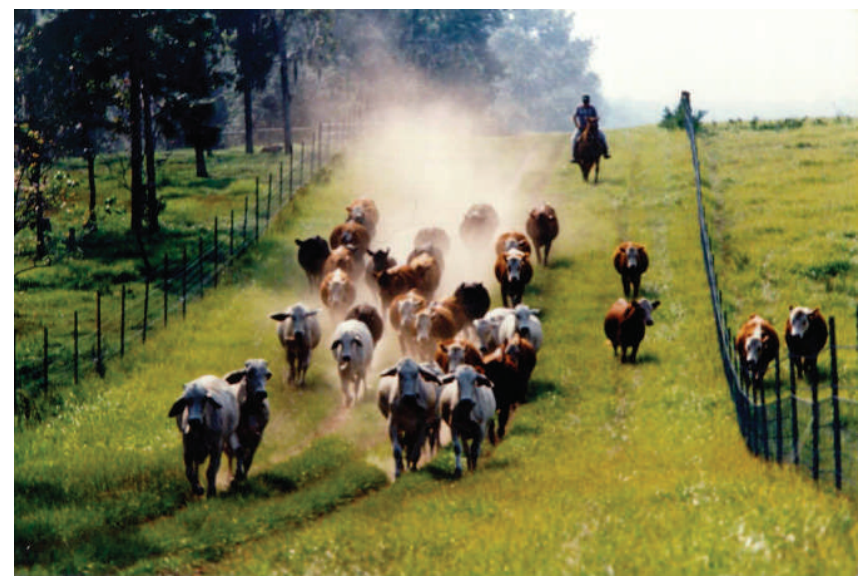

Figure 1. Cattle producers planted introduced forages, such as bahiagrass, after the native rangeland vegetation communities were made less productive by unregulated grazing.

sular Florida. By 1999, approximately 300,000 acres of land, or more than 460 square miles, had been mined for phosphate. ${ }^{4}$ Wildlife in those areas suffered because reclamation (e.g., "made suitable for beneficial use or habitat") of mined lands was not required for the almost 150,000 acres mined before 1975., Additionally, post-1975 mining regulations require only acre-for-acre replacement of wetland communities. ${ }^{4}$ In a 1989 regional conceptual plan, post-1975 mining and reclamation was predicted to result in an $81 \%$ and $51 \%$ decline in the remaining acreage of native rangeland and upland forestland, respectively, in mineable areas. ${ }^{5}$ Much of that decline was due to conversion to pastureland because planting nonnative pasture species, such as bahiagrass, has been the easiest revegetation method to use. ${ }^{5}$ Exacerbating habitat loss by deliberate conversion of native ecological communities to pastureland was the presence of exotic invasive species, such as cogongrass (Imperata cylindrica), which has become established as a monoculture over large areas of mined land awaiting restoration. ${ }^{6}$ Mining operations are now mandated by law to have a reclamation plan that is submitted to the Florida Department of Environmental Protection and other local, state, and federal agencies for approval, and wildlife considerations are included in these plans.

\section{Current Demand for Native Plant Materials}

In recent years, there has been an increasing interest in both the public (e.g., state agencies, water management districts, county environmental agencies, etc.) and private sectors (e.g., mining industry, mitigation banks, private landowners restoring converted lands to wildlife habitat, etc.) in revegetating areas of Florida with native species. ${ }^{7}$ This is due, in part, to the perception that native species provide better wildlife food and habitat and offer more sustainable management systems because of lower nutrient requirements. Technical issues associated with revegetation efforts, at a minimum, range from eradicating aggressive, nonnative, sod-forming forage spe$\operatorname{cies}^{8}$ to the whole gamut of issues associated with mineland

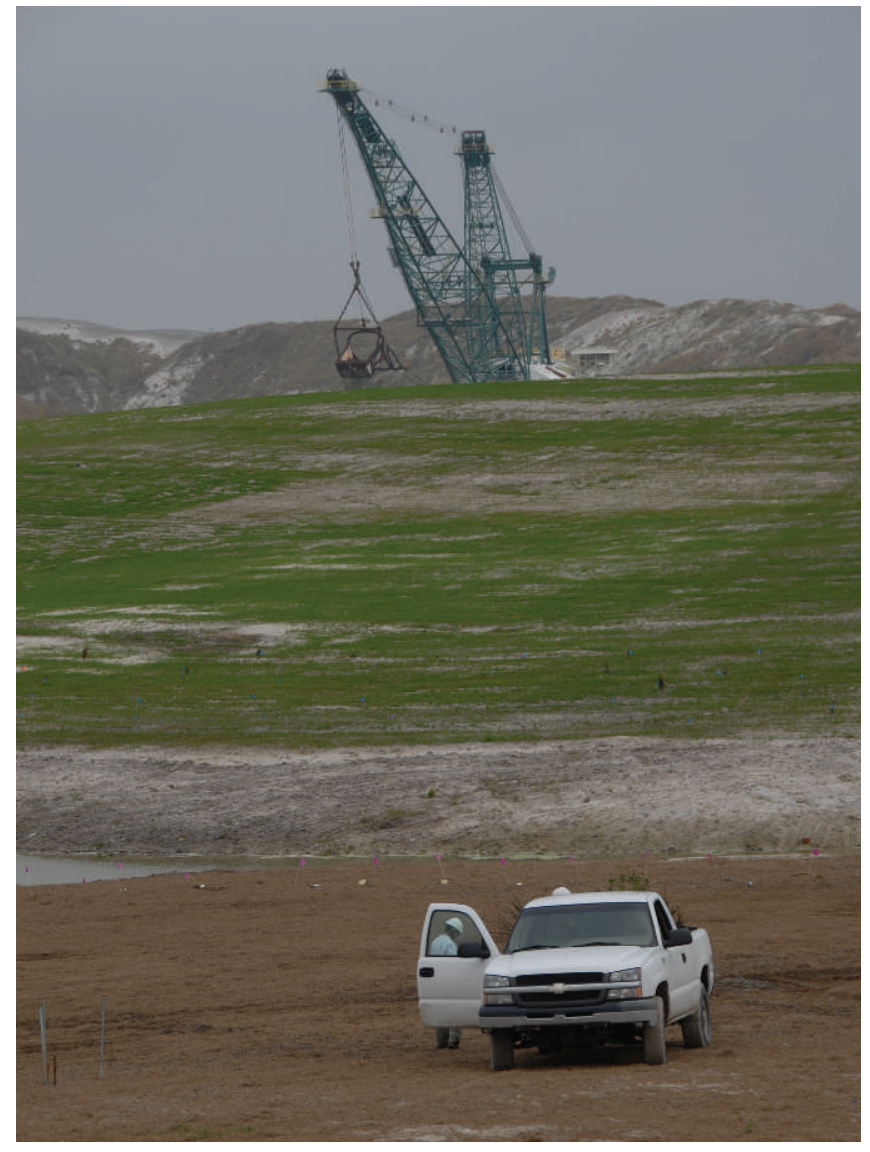

Figure 2. In some cases, conversion of native rangeland vegetation was the result of industrial activities, such as phosphate mining.

reclamation, which include hydrology, water quality, wetland and other wildlife habitat replacement and mitigation, native vegetation establishment, and exotic weed control. ${ }^{4}$

One of the most expensive components of native revegetation projects is the cost of acquiring the seed of native species. Because of the lack of commercial seed sources for essentially all Florida native species, current revegetation efforts use both mechanical and hand-harvested seed from natural stands, which by some estimates costs $\$ 1,000$ per acre for the seed alone. ${ }^{7}$

Lack of commercial seed sources for Florida native species has been partly due to many of the Florida native grasses being poor seed producers. ${ }^{9} 10$ Also Florida's species evolved under a natural fire regime, and some species require fairly specific burning regimes to produce any quantity of viable seed. ${ }^{11}$ Additionally, commercial seed producers in the state lacked both the specialized equipment and the experience needed to grow these types of species, which made them very reluctant to put any private effort into native seed production. Lack of interest by commercial entities, combined with the historically low priority for researchers at Florida state universities in conducting research with native grass species, meant that essentially nothing was being done to improve the availability and reduce the cost of Florida ecotypes of native grass seed. 


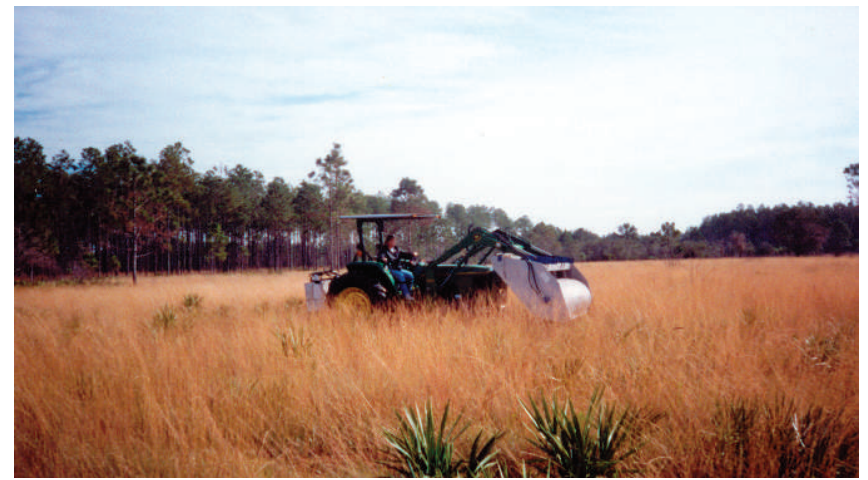

Figure 3. Wild harvest of wiregrass seed with flail-vac at Avon Park bombing range.

\section{Initial Efforts for Native Grass Seed Production in Florida}

It was apparent that a systematic approach was necessary to identify the most suitable native species for use on restoration sites and to develop the technology necessary for commercial seed production. Developing native, warm-season grasses for cattle pastures and wildlife habitat has been an important mission of the USDA Natural Resources Conservation Service (NRCS), Plant Materials Program at the Brooksville Plant Materials Center (PMC) in Brooksville, Florida.

In the early 1990s, the Brooksville PMC joined with the Florida Institute of Phosphate Research (now Florida Industrial and Phosphate Research Institute) to develop seed sources for Florida native ecotypes. Early work involved the screening of a wide range of native species for growth characteristics and seed production. ${ }^{9,12}$ Additionally, these organizations developed information about the management and production of seed from specific Florida native species. ${ }^{13}$ As a continuation of the initial screening program, the current focus of the Brooksville PMC is to develop reliable seedproducing cultivars or germplasm for the grasses that were identified as suitable species for revegetation efforts and to facilitate their commercial availability.

\section{How Native Grass Germplasm Is Developed in the Plant Materials Program}

Because this material is to be used over a wide area and not a specific locale (e.g., park or preserve), as wide a genetic range of material needed to be assembled from within the ecoregion. With the help of local NRCS personnel and the PMC staff, effort was made to locate at least three sources of each species in each county in the state, with the restriction that the sources be no closer than five miles apart. This resulted in the assembly of between 50 and 150 accessions of each grass species. These accessions were planted in replicated space plant trials and evaluated for such factors as establishment rate, growth, and seed production for 1-4 years. At that point, accessions that were rated as superior were selected, and progeny of those superior accessions underwent additional evaluation phases designed to demonstrate heritability of superior characteristics (usually 2-3 years) and to determine range of adaptation (usually $2-3$ years).

Because of differing consumer goals when using native seeds, the NRCS Plant Materials Program adopted release designations that described the level of testing different plant materials have undergone. ${ }^{14}$ It was understood that the earlier a species was in its evaluation program when it was released, the greater was the risk assumed by producers and reclamationists in seed production and survival of the material. "Source-identified" germplasm has had essentially no testing and is simply what it states: germplasm from the location where it was collected. "Selected" germplasm is the release designation for superior material identified after the initial evaluation. If germplasm was released after the advanced evaluation phase, where the heritability of desired characteristics was proven, it received a classification of "Tested" germplasm. Only after the superior germplasm has undergone all advanced evaluation phases, including regional evaluation trials, will it be released under the designation "Cultivar."

\section{Status of Native Grass Seed Lines for Florida}

Purple bluestem is one of the most important species found on native range sites and is usually found around water bodies and in wetter flatwoods sites. It is a good seed producer with excellent potential for erosion control, water quality, forage, and wildlife cover. A total of 91 accessions were collected from 43 counties in the fall of 1996. Transplanted seedlings and direct-seeded plants (only 88 accessions) were evaluated for 2 years and 3 years, respectively, for 12 different criteria, including plant survival, vigor, plant height, basal width, bloom date, seed-maturity date, seed production, and seed viability. The 10 accessions that ranked highest in the largest number of criteria over all years of testing were planted in an increase polycross block to form a composite germplasm. ${ }^{15}$ Seed from that crossing block was collected in 2002 and was used to establish a breeder seed nursery. The material was released in 2006 as Ghost Rider Selected Germplasm (NRCS accession number 9060461). ${ }^{15}$

Splitbeard bluestem (Andropogon ternarius) is not considered to be a major component of the ecosystems in which it occurs. It is classified as a midsuccessional species that will form fairly stable communities with broomsedge and panicgrasses (Panicum spp.) in abandoned fields and disturbed areas. This type of community generally persists as long as fire prevents encroachment of woody species. Only one accession (9060084) of splitbeard bluestem was evaluated by PMC personnel. It was included in testing conducted from 1997 to 2001 of direct-seeding methods to revegetate phosphate minelands in Florida. In that study, 34 accessions of grasses and forbs were evaluated. The splitbeard bluestem accession consistently germinated and established better on sand tailings, where it was exposed to extreme drought conditions, than any of the other species tested. ${ }^{9,13}$ This species was not nearly as robust and vigorous on overburden soils, likely because of the higher clay content that is often found in those 


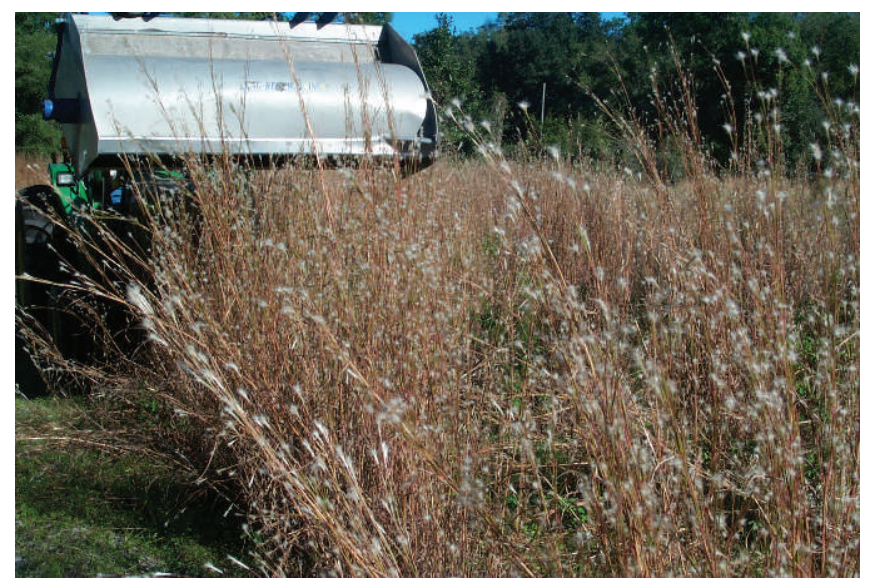

Figure 4. Flail-vac harvest of breeder block of Ghost Rider Selected Germplasm purple bluestem.

substrates. The accession was located on dry sandhills in the northern portion of Ft. Cooper State Park, near the city of Inverness, Florida. The splitbeard bluestem accession was released in 2008 as Ft. Cooper Source-Identified Germplasm to meet an identified need to increase the availability of native grass seed sources that have demonstrated high establishment potential and desirable growth characteristics for use in Florida natural area and rangeland plantings.

Eastern gamagrass is a species that has undergone extensive evaluation and cultivar development throughout the eastern United States. It grows on moist, fertile sites and is typically found on canal banks or ditches in Florida. An assembly of Florida ecotypes was evaluated in 1996 and 1997. As part of that evaluation, seed was collected weekly during the growing season, and the amount of viable seed was determined. Although Florida ecotypes were found to produce seed from June through August, the maximum viable seed amount was found in the last 2 weeks of August in both years. In a multilocation (Georgia, Mississippi, Alabama, and Texas) evaluation trial, Florida accessions of eastern gamagrass failed to survive through winter in all locations, except Georgia and Florida (C. Maura, Jr., unpublished data, 1998). Those Florida accessions had no real dormancy mechanisms and would begin regrowth too early in the spring to survive. Lack of dormancy does explain the superior forage production associated with Florida accessions in Florida when compared to eastern gamagrass selections originating in more-northern locations. Accession 9059266 from Polk County, Florida, was identified for release because of its superior forage and seed production. Seed production is being increased in Brooksville and at the University of Florida, North Florida Research and Education Center in Marianna. A joint NRCS and University of Florida germplasm release is anticipated in 2015.

Switchgrass is perhaps the most widely studied native species in the United States. As with eastern gamagrass, switchgrass selections or cultivars originating outside of Florida have proved to be less-persistent than selections originating within the state. Seed production has been a problem for Florida ac-

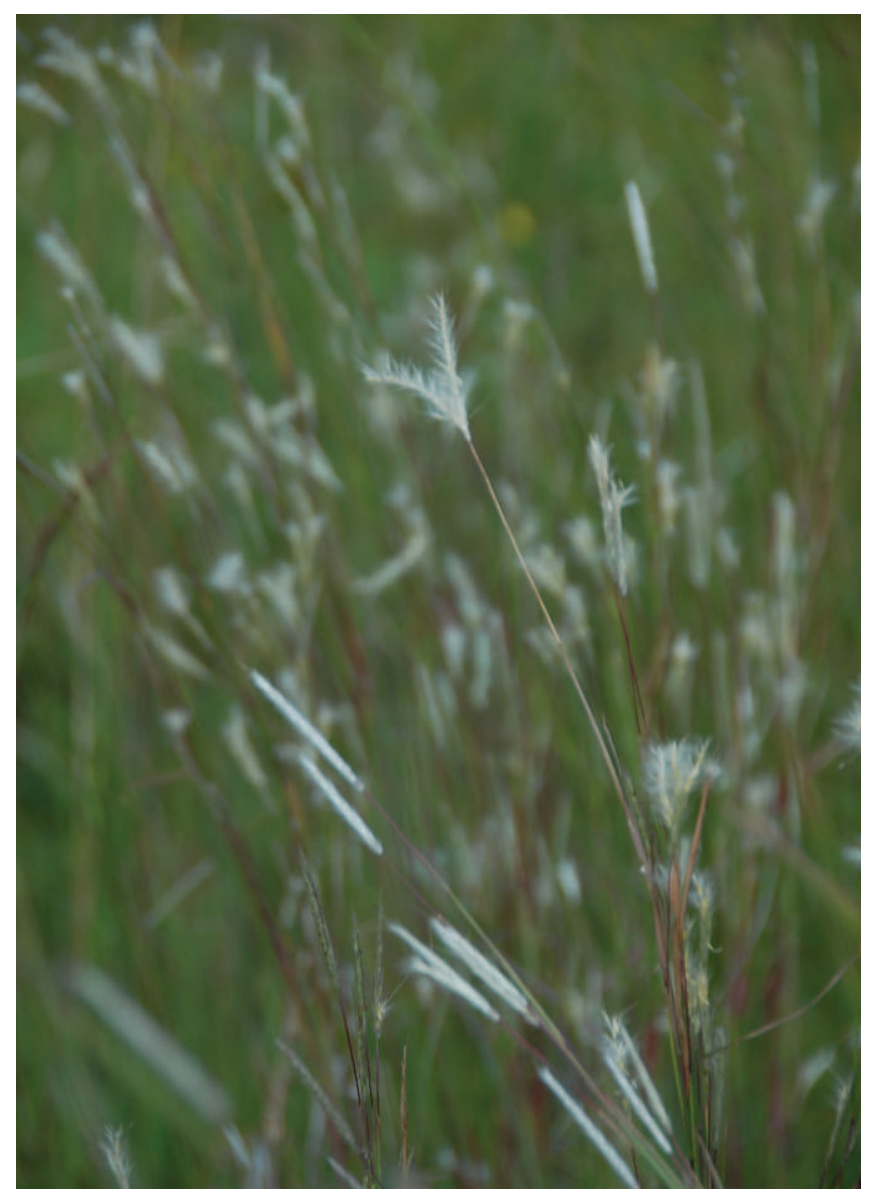

Figure 5. Seed heads of Ft. Cooper Source-Identified Germplasm splitbeard bluestem.

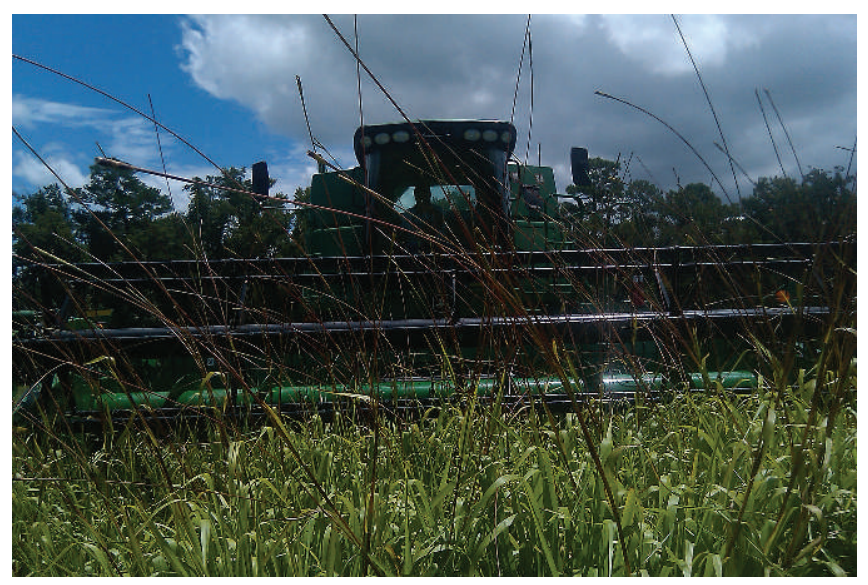

Figure 6. Combining breeder seed of soon-to-be-released Florida ecotype of eastern gamagrass at the Brooksville PMC.

cessions. The Brooksville PMC has initiated a cooperative breeding program with the University of Florida to develop seed-producing lines of switchgrass based on Florida ecotypes. A statewide collection of 98 switchgrass accessions was made in 1999-2000, and initial evaluation of space plants was conducted in 2003 and 2004 (C. Maura, Jr., unpublished data, 2005). In 2012, remaining accessions were screened to deter- 


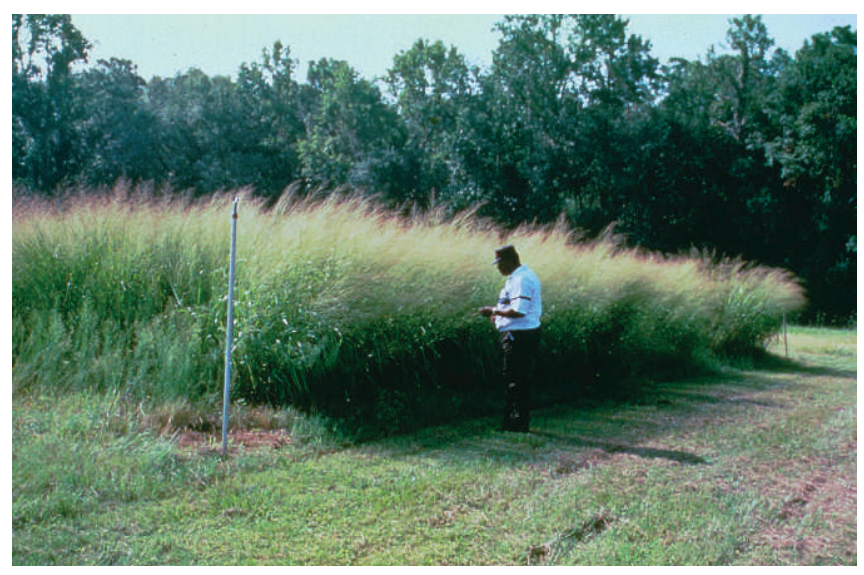

Figure 7. Previous releases of Florida ecotypes of switchgrass, such as the Miami cultivar shown here, can produce tremendous biomass, but relatively little viable seed.

mine ploidy level of the material so that superior accessions of similar ploidy level could be selected and crossing blocks be established. The main emphasis of that work, which is expected to extend into the next decade, will be to develop commercially viable, seed-producing, Florida germplasm.

\section{In the Future}

During the past 30 years, an extensive amount of work has been conducted toward the goal of developing commercially viable, seed-producing, native species for Florida. The pressing need for that material must be balanced with the need for accompanying technology development to ensure successful stand establishment.

\section{References}

1. West Florida Research and Education Center, UniVERSITY OF FLORIDA. 2008. Range sites of Florida. Available at: http://wfrec.ifas.ufl.edu/Subsites/RangeScience/rangelands/. Accessed 11 July 2013.

2. West Florida Research Education Center, UniverSITY of Florida. 2008. Range grasses of Florida. Available at: http://wfrec.ifas.ufl.edu/Subsites/RangeScience/grasses/. Accessed 11 July 2013.

3. Institute of Food Agricultural Science, University of FLORIDA. 2007. Forages of Florida. Available at: http://agronomy. ifas.ufl.edu/foragesofflorida/species_grasses.php. Accessed 11 July 2013.

4. Florida Industrial Phosphate Research Institute. 2010. Phosphate primer. Available at: http://www1.fipr.state. fl.us/PhosphatePrimer. Accessed 11 July 2013.

5. Cates, J. W. H. 1992. The Regional conceptual plan for the Southern Phosphate District of Florida. 179 p. Tallahassee, FL, USA: Florida Department Environmental Protection, Bureau Mine Reclamation. Available at: http://www.dep.state.fl.us/ water/mines/ihn/docs/RegionalConceptualPlan_So_ Phosphate_District_FL.pdf. Accessed 11 July 2013.
6. Institute Food Agricultural Science, Extension, UniVERSITY OF FloridA. Invasive grass cogongrass. Available at: http://solutionsforyourlife.ufl.edu/hot_topics/environment/ cogongrass.html. Accessed 11 July 2013.

7. Trusty, J. L., And H. K. Ober. 2009. Groundcover restoration in forests of the Southeastern United States. Gainesville, FL, USA: University of Florida, Conserved Forest Ecosystem Outreach and Research. Report 2009-01. 115 p. Available at: http:// www.sfrc.ufl.edu/cfeor/docs/Groundcover\%20booklet $\% 20$ Sep2010\%20low\%20res.pdf. Accessed 12 July 2013.

8. McCollom, J. 2005. Restoration of native groundcover vegetation on abandoned improved pasture as Okaloacoochee Slough Wildlife Management Area. West Palm Beach, FL, USA: South Florida Water Management District. 95 p. Available at Shttp://www.sfwmd.gov/portal/page/portal/xrepository/sfwmd_ repository_pdf/report $\% 20$ to\% 20 sfwmd\%20for\%20pasture \%20restoration\%20grant\%2012-05.pdf. Accessed 11 July 2013.

9. Pfaff, S. L., And M. A. Gonter. 1996. Florida native plant collection, production, and direct seeding techniques: interim report. Brooksville, FL, USA: USDA, NRCS, Brooksville Plant Materials Center. $61 \mathrm{p}$.

10. YARLETT,L.L.1996. Common grasses of Florida and the southeast. Spring Hill, FL, USA: Florida Native Plant Society. 216 p.

11. Platt, W. J., G. W. Evans, and M. M. Davis. 1994. Effects of fire season on flowering of forbs and shrubs in longleaf pine forests. Oecologia 76:353-363.

12. Pfaff, S., and M. A. Gonter. 2000. Seeding two native grass species on reclaimed phosphate minedlands. In: W. L. Daniels and S.G. Richardson [eDs.]. Proceedings of the 2000 Annual Meeting American Society for Surface Mining and Reclamation; 11-15 June 2000; Tampa, FL, USA. Lexington, KY, USA: American Society of Surface Mining Reclamation. p. 49-61.

13. Pfaff, S., M.A. Gonter, and C. Maura. 2002. Florida native seed production manual. Brooksville, FL, USA: USDA, NRCS, Brooksville Plant Materials Center. 65 p.

14. Kujawski, J., And D. Ogle. 2005. Not your grandpa's cultivars: the new conservation releases. Native Plants Journal 6:49-51.

15. Grabowsкi, J. 2006. Notice of release of ghost rider germplasm purple bluestem selected class of natural germplasm. Brooksville, FL, USA: USDA, NRCS, Brooksville Plant Materials Center.

Authors are State Agronomist/Plant Materials Specialist, Natural Resources Conservation Service, US Dept of Agriculture, Gainesville, FL 33513, USA (M. J. Williams); Manager, Brooksville Plant Materials Center, Natural Resources Conservation Service, US Dept of Agriculture, Brooksville, FL 32601, USA (Grabowski); and Rangeland Management Specialist, Natural Resources Conservation Service, US Dept of Agriculture, Palmetto, FL 34221, USA, brandee.williams@fl.usda.gov (B. Williams). 